\title{
Importance of Biochemical Investigations, Electrocardiography and Ambulatory Blood Pressure Monitoringin Primary Health in Hypertensive Elderly Patients Management
}

\begin{abstract}
SIMINA-AMELIA DEJICA, IOAN DEMETER*, ERWIN FLORONI, ANDREI NEAMTU, DANIELA GURGUS, SORIN URSONIU, VIRGIL CIOBANU

University of Medicine and Pharmacy Victor Babes Timisoara, Faculty of Medicine, 2 Eftimie Murgu Sq., 300041, Timisoara, Romania

According to SEPHAR studies I, II and III conducted in Romania the prevalence of hypertension increased, decreased and again increased in more than 10 years from 44.92 to $40.1 \%$ and than to $45.1 \%$, expecting more good results in further years. Ambulatory blood pressure monitoring (ABPM) is the main method used by family doctors in primary health carefor detectingthe variability of blood pressure $(B P)$, and treatment response. The goals of this study were to identify the electrocardiographic presence of the left ventricular hypertrophy( LHV)in elderly hypertensive patientsand analyze the differences between those who have controlled hypertension and those who have white-coat, masked or sustained hypertension so to highlight the importance of using ABPM in the primary care service in Romania.
\end{abstract}

Keywords: ambulatory blood pressure monitoring, left ventricular hypertrophy, hypertension, elderly, primary health care

According to SEPHAR studies I, II and III conducted in Romania the prevalence of hypertension increased in lastten years from $44.92 \%$ to $45.1 \%$, expecting to increase also in further years[1-3].Taking this into account and knowing as well that hypertension is increasing with age, and only $30.8 \%$ of hypertensive patients have blood pressure (BP) controlled [3], it is necessary for general practitioners to pay more attention especially to elderly hypertensives, conducting investigations that quickly reveal cardiac damage, and quantify cardiovascular risk.

Although clinic BP monitoring is the first method of detecting hypertension and further treatment results it may have some drawbacks especially with BP patterns that are so common in both treated and untreated hypertensive patients like masked hypertension(which means normal clinic BP and elevated ambulatory BP) and white-coat hypertension(which means elevated clinic BP and normal ambulatory $B P)[4,5]$. Therefore ambulatory blood pressure monitoring(ABPM) is the main method of detecting the variability of BP andtreatment response and furthermore, it is used toemphasize the correlation between BP patterns and cardiac damage like left ventricular hypertrophy(LVH)[6-10].

Several studies demonstrated a strong correlation between LVH and ABPM either determined echocardiographically or electrocardiographically[11-13], but we didn't find studies thatpresented this kind of correlation in hypertensive treated elderly in the medical family practice, in Romania.

The goals of this study were to identify the electrocardiographic presence of the LVH in hypertensive elderly, and the differences between those who have controlled hypertension and those who have white-coat, masked or sustained hypertension with the purpose to highlight the use of ABPM in the primary care service in Romania.

\section{Experimental part}

Material and methods

Study population and design

Data of this observational cross-sectional study were gathered by the participation of three primary health care practice from Timis County Romania. All participants at the study were known hypertensives for at least oneyear by their own general practitioner doctor. Period of study inclusion was from January 2017 until January 2018. Inclusion criteria were: patients aged 65 years or older, under antihypertensive treatment for at least one year, with optimal ABPM (more than $23 \mathrm{~h}$ recording, minimum two valid measurements/hour, equals more than $70 \%$ of the measures). Were excluded from the study newly discovered hypertensives and patients who exhibit technical difficulty with ABPM, meaning problems in the reading, or those who didn't tolerate the equipmentbecause of anxiety orbecause of the discomfort given by wearing the cuff.

Categories according to age: young old (65-74 years), middle old (75-84 years) and oldest old $\geq 85$ years.

BP targets were defined as normal clinic blood pressure $\leq 140 / 90 \mathrm{mmHg}$; normal ambulatory blood pressure: $24 \mathrm{~h}$ BP <130/80mmHg; daytime systolic blood pressure (SBP) $\leq 130 \mathrm{mmHg}$ and diastolic BP $\leq 85 \mathrm{mmHg}$; night-time systolic BP $\leq 120 \mathrm{mmHg}$ and diastolic blood pressure (DBP) $\leq 80 \mathrm{mmHg}[14]$;

For ABPM pattern BP was defined as:

-Controlled hypertension(CH)- normal clinic BP and normal ambulatory blood pressure;

-The white-coat effect in uncontrolled hypertension(WCEUH)-raised clinic BP and normal ambulatory blood pressure;

-The masking effect in uncontrolled hypertension(MEUH)- normal clinic BP and raised ambulatory blood pressure; 
-Sustained uncontrolled hypertension(SUH)- raised clinic BP and raised ambulatory blood pressure $[15,16]$.

Pulse Pressure(PP) was defined as the difference between the systolic and diastolic blood pressure for the clinic and ambulatory blood pressure[14].

For 24h ambulatory blood pressure monitoring nocturnal dipping was defined as night-day blood pressure ratio with the following categories: extreme dippers $>20$, dippers between 10 and $20 \%$, nondippers between $0 \%$ and $10 \%$ and reverse dippers ratio less than $0 \%[14,17]$.

Electrocardiographic LVH was identified when index Sokolow-Lyon: SV1+ RV5 $>3.5 \mathrm{mV}$, index Sokolow-Lyon modified: larger S+ larger $\mathrm{R} \geq 3.5 \mathrm{mV}, \mathrm{R}$ in $\mathrm{aVL} \geq 1.1 \mathrm{mV}$ or index Cornell modified: product between voltage and duration of $\mathrm{QRS} \geq 244 \mathrm{mV} * \mathrm{~ms}[14]$.

Body mass index(BMI) was calculated as weight, in kilograms, divided by square height in square meters. Were defined three categories: BMI less than $25 \mathrm{~kg} / \mathrm{m}^{2}$ as normal weight, BMI between $25 \mathrm{~kg} / \mathrm{m}^{2}$ and $29.9 \mathrm{~kg} / \mathrm{m}^{2}$ as overweight, and BMI more or equal than 30 as obese.

\section{Clinical data, anthropometric measurements, biochemical tests}

At the visit to the office anthropometric measurements (body weight in kilograms, height in centimeters) were made after the measurement for clinic BP, and BMI was calculated.

Biochemical tests were done to asses lipid profile: total serum cholesterol(Total Cholesterol) in $\mathrm{mg} / \mathrm{dL}$, highdensity lipoprotein cholesterol( $\mathrm{HDL}_{\mathrm{C}}$ ) in $\mathrm{mg} / \mathrm{dL}$, low-density lipoprotein cholesterol in mg/dl ( $\left(\mathrm{LL}_{\mathrm{c}}\right)$, Triglycerides in $\mathrm{mg} /$ dl.

Clinic BP was measured by the general practitioner, using a calibrated mercury sphygmomanometer, with the patient in the sitting position after 5 min of rest, using every time an adequate sized cuff. According to the auscultatory technique, systolic BP was defined by phase 1 Korotkoff sound and diastolic BP by phase 5 Korotkoff sound. The mean from three measurements made after $5 \mathrm{~min}$ rest, at 3 min distance was taken as the value for clinic BP. Hypertension on the elderly was defined as BP $\geq 140$ / $90 \mathrm{mmHg}$ [6]. Clinic pulse pressure was calculated.

ABPM technique was done by a trained assistant after the measurement for clinic BP. A calibrated twenty-fourhour Holter TA, with an adequate sized cuff, was used for the measurements. Twenty four hours BP was done by all participants. Measurement settings were made at $15 \mathrm{~min}$ during daytime(between 07:00 am and 11:00 pm) and 30 min during night-time(between 11:00 pm an 07:00 am).
For each of the participants was taken into account mean of the following values $24 \mathrm{~h}$ systolic BP, $24 \mathrm{~h}$ diastolic BP, daytimeSBP, night-timeSBP, daytimeDBP, night-time DBP. Daytime, night-time pulse pressure, as well as nocturnal dipping for both systolic and diastolic blood pressure, were calculated.

Ethics:The study is in accordance with the World Medical Association Helsinki Declaration. The research protocol was approved by the Ethics Committee of the University of Medicine and Pharmacy Victor Babes Timisoara and all participants gave their informed consent at the beginning of the study.

\section{Data analysis}

Statistical analyses were done with SPSS version 20 with a significance level of $p$ value $<0.05$. Using descriptive statistics continuous variables were reported as mean and $\mathrm{SD}$ and categorical variables were reported as frequency and percentage. The differences between BP pattern were evaluated with Pearson chi-square test.

\section{Results and discussions}

We identified two-hundred and forty-three elderly treated hypertensive aged more than 65 years, who met the inclusion criteria in the study. Descriptive clinical and anthropometric characteristics of the study population according to age are pointed out in table 1. The profile of the patients included in the study was young old(67.1\%) female (58,.3\% from total group), living in urban area $(68.1 \%)$, with controlled hypertension $(44.2 \%)$, past smokers (46\%), occasionally alcohol consumption(46\%), which is appropriate with the general profile of Romanian hypertensive patients from Sephar II study [18], only that in our study we included only elderly treated hypertensive patients age 65 years or more.

From our sample in the young-old category half of the cohort had controlled hypertension (44.2\%), followed by those who had SUH and $\operatorname{MEUH}(21.5 \%)$, then from those who had WCEUH (12.5\%). In the middle-old category, the percentage of patients who had $\mathrm{CH}$ is equal with those who had SUH(36.2\%), but there was a change in the percentage of those with MEUH and WCEUH respectively less with MEUH $(13 \%)$ and more with WCEUH $(14.5 \%)$. In the oldest-old category, only $9.1 \%$ of them had SUH, many of them were instead with $\mathrm{CH}(45.5 \%)$, and then again the percentage of those with MEUH(18,2\%) was smaller than the percentage of those with WCEUH(27.3\%). If we take into account only these percentages we can say that the oldest-oldage group patients had the most frequent BP

\begin{tabular}{|c|c|c|c|c|c|c|}
\hline & & \multicolumn{3}{|c|}{ Age Groups } & \multirow{2}{*}{ Total } & \multirow{14}{*}{$\begin{array}{c}\text { Table } \mathbf{1} \\
\text { BASELINE } \\
\text { CHARACTERISTICS OF } \\
\text { THE STUDY ACCORDING } \\
\text { TO AGE. }\end{array}$} \\
\hline & & $\begin{array}{l}\text { young-old } \\
67.1 \%\end{array}$ & $\begin{array}{l}\text { middle-old } \\
28.4 \%\end{array}$ & $\begin{array}{l}\text { oldest-old } \\
4.5 \%\end{array}$ & & \\
\hline$\overline{\text { Gender }}$ & Female & $58.3 \%$ & 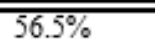 & $\overline{54.5 \%}$ & $\overline{57.6 \%}$ & \\
\hline Region & Urban & $68.1 \%$ & $59.4 \%$ & $90.9 \%$ & $66.7 \%$ & \\
\hline \multirow{4}{*}{$\begin{array}{l}\text { Hypertension } \\
\text { Patterns }\end{array}$} & $\mathrm{CH}$ & $44.2 \%$ & $36.2 \%$ & $45.5 \%$ & $42.0 \%$ & \\
\hline & WCEUH & $-12.9 \%$ & $14.5 \%$ & $27.3 \%$ & $14.0 \%$ & \\
\hline & $\mathrm{MEUH}^{-}$ & $21.5 \%$ & $13.0 \%$ & $18.2 \%$ & $18.9 \%$ & \\
\hline & $\mathrm{SUH}^{-}$ & $21.5 \%$ & $36.2 \%$ & $9.1 \%$ & $25.1 \%$ & \\
\hline \multirow[t]{3}{*}{ Smokers } & Yes & $19.6 \%$ & $14.5 \%$ & $36.4 \%$ & $18.9 \%$ & \\
\hline & No & $34.4 \%$ & $39.1 \%$ & $27.3 \%$ & $35.4 \%$ & \\
\hline & Past smokers & $46.0 \%$ & $46.4 \%$ & $36.4 \%$ & $45.7 \%$ & \\
\hline \multirow{3}{*}{$\begin{array}{l}\text { Alcohol } \\
\text { consumption }\end{array}$} & Yes & $11.7 \%$ & $10.1 \%$ & $9.1 \%$ & $11.1 \%$ & \\
\hline & No & $42.3 \%$ & $-53.6 \%$ & $36.4 \%$ & $45.3 \%$ & \\
\hline & Occasional & $46.0 \%$ & $36.2 \%$ & $54.5 \%$ & $43.6 \%$ & \\
\hline
\end{tabular}

Note.CH-Controlled hypertension, WCEUH-White-coat effect in uncontrolled hypertension, MEUH-Masked effect in uncontrolled hypertension, SUH-Sustained uncontrolled hypertension. 
pattern $\mathrm{CH}$ and WCEUH and youngest-old age group patients had the most frequent $\mathrm{BP}$ pattern $\mathrm{CH}$, MEUH, and SUH. Mean age in all BP pattern category was $73.31 \pm 5.42$ (table 2) meaning that most of the patientsare youngestold. We also have to specify that the prevalence of masked effect is bigger than the prevalence of white-coat effect but smaller than the prevalence of sustained hypertension in treated elderly hypertensive patients which is appropriate with the results of other studies $[15,19,20]$ where was proved that these BPpatterns are predictors for higher risk of LVH.Prevalence of smokers among BP patterns, presented in figure 1, was bigger in $\mathrm{CH}$ versus SUH and in MEUH versus WCEUH, butwithin these, we identified many past smokers than smokers with all reports above repeated.

Biochemical and anthropometric characteristics of the study group, pointed out in tabel 2, brings in front,thatour cohort is made from overweightpatients (BMI 32.63 \pm 5.37 , $\mathrm{kg} / \mathrm{m} 2$ ) withlipid profile not in good limits (Total cholesterol

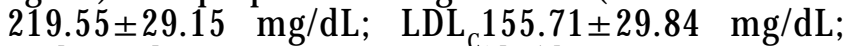
triglycerides $144.36 \pm 31.76 \mathrm{mg} / \mathrm{dL}$;) but appropriate as values in all BP pattern category which differs from the

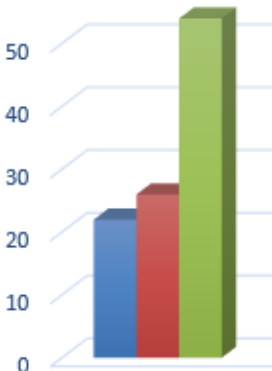

$\mathrm{CH}$

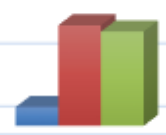

WCEUH

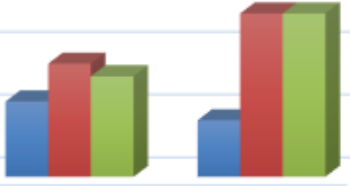

SUH
- yes no vast smokers

Fig. 1. Prevalence of smoking status among BP patterns

cohort of other studies where lipid profile was different among BP patterns e.g. Pierdomenico SD. etal. in his study [15]:LDL $\mathrm{Las}_{\mathrm{C}}$ lower in WCUCH than in $\mathrm{CH}$ and $\mathrm{SUCH}$. HDL was higher at MEUH group and the differences between groups were statistically significant $(p=0.01)$.

Table 2

BIOCHEMICAL AND ANTHROPOMETRIC CHARACTERISTICS OF THE STUDY GROUP

\begin{tabular}{|c|c|c|c|c|c|c|}
\hline & $\begin{array}{c}\mathrm{CH} \\
\mathrm{n}=106\end{array}$ & $\begin{array}{c}\text { WCEUH } \\
\mathrm{n}=34\end{array}$ & $\begin{array}{c}\text { MEUH } \\
\mathrm{n}=46\end{array}$ & $\begin{array}{l}\text { SUH } \\
n=61\end{array}$ & $\begin{array}{c}\text { TOTAL } \\
\mathrm{n}=\mathbf{2 4 3}\end{array}$ & $\mathbf{p}$ \\
\hline Gender $\%$ & $53.9 \%$ & $41.2 \%$ & $63.0 \%$ & $68.9 \%$ & $57.6 \%$ & 0.86 \\
\hline Age, years & $72.88 \pm 5.39$ & $74.12 \pm 6,074$ & $72.67 \pm 5.26$ & $74.05 \pm 5.19$ & $73.31 \pm 5.42$ & 0.65 \\
\hline Body Mass Index, $\mathrm{kg} / \mathrm{m}^{2}$ & $32.47 \pm 5.36$ & $33.02 \pm 5,66$ & $33.49 \pm 5.96$ & $32.03 \pm 4.76$ & $32.63 \pm 5.37$ & 0.21 \\
\hline Total Cholesterol, $\mathrm{mg} / \mathrm{dl}$ & $218.60 \pm 29.62$ & $217.32 \pm 33.15$ & $219.28 \pm 26.07$ & $222.59 \pm 28.70$ & $219.55 \pm 29.15$ & 0.18 \\
\hline $\mathrm{HDL} \mathrm{c}, \mathrm{mg} / \mathrm{dl}$ & $59.72 \pm 11.37$ & $66.56 \pm 8.836$ & $68.48 \pm 9.80$ & $65.72 \pm 13.61$ & $63.84 \pm 11.90$ & 0.01 \\
\hline $\mathrm{LDL}_{\mathrm{c}}, \mathrm{mg} / \mathrm{dl}$ & $158.88 \pm 28.62$ & $150.76 \pm 32.27$ & $150.80 \pm 29.28$ & $156.87 \pm 30.77$ & $155.71 \pm 29.84$ & 0.73 \\
\hline Triglycerides, mg/dl & $146.01 \pm 33.37$ & $139.71 \pm 32.21$ & $140.80 \pm 29.28$ & $146.87 \pm 30.77$ & $144.36 \pm 31.76$ & 0.62 \\
\hline
\end{tabular}

Table 3

CHARACTERISTICS OF HYPERTENSION PATTERNS ACCORDING TO THE CLINIC AND AMBULATORY BLOOD PRESSURE MONITORING

\begin{tabular}{|c|c|c|c|c|c|}
\hline & \multicolumn{4}{|c|}{ Hypertension Patterns } & \multirow[b]{2}{*}{$\begin{array}{l}\text { TOTAL, } \\
n=243\end{array}$} \\
\hline & $\begin{array}{l}\mathrm{CH}, \\
\mathrm{n}=102\end{array}$ & $\begin{array}{l}\text { WCEUH, } \\
\mathrm{n}=34\end{array}$ & $\begin{array}{l}\text { MEUH, } \\
\mathrm{n}=46\end{array}$ & $\begin{array}{l}\text { SUH, } \\
\mathbf{n}=61\end{array}$ & \\
\hline Clinic SBP, mmHg & $127.27 \pm 6.22$ & $161.86 \pm 10.73$ & $127.43 \pm 5.36$ & $163.95 \pm 13.36$ & $141.35 \pm 19.74$ \\
\hline Clinic DBP, mmHg & $70.24 \pm 4.73$ & $94.34 \pm 2.85$ & $79.43 \pm 7.48$ & $95.87 \pm 2.16$ & $81.78 \pm 12.30$ \\
\hline Clinic $\mathrm{PP}, \mathrm{mmHg}$ & $57.03 \pm 3.86$ & $67.52 \pm 9.51$ & $48.00=8.02$ & $68.08=11.96$ & $59.56=11.01$ \\
\hline $24 \mathrm{~h} \_\mathrm{SBP}, \mathrm{mmHg}$ & $119.64 \pm 1.53$ & $122.86 \pm 1.18$ & $140.37 \pm 2.25$ & $149.31 \pm 4.46$ & $131.46=13.10$ \\
\hline $24 \mathrm{~h} \_\mathrm{DBP}, \mathrm{mmHg}$ & $72.33=1.26$ & $75.16 \pm 0.88$ & $87.31=0.88$ & $89.93 \pm 0.87^{-}$ & $79.98=8.01$ \\
\hline $24 \mathrm{~h} \_\mathrm{PP}, \mathrm{mmHg}$ & $-47.32 \pm 0.32$ & $47.70 \pm 0.37$ & $53.05 \pm 1.38$ & $59.38 \pm 3.61$ & $51.48 \pm 5.40$ \\
\hline ABP Daytime SBP, mmHg & $-120.73 \pm 1.69$ & $124.30=1.46$ & $-143.11=2.81$ & $153.36 \pm 5.29$ & $133.66 \pm 14.40$ \\
\hline $\mathrm{ABP}$ Daytime $\mathrm{DBP}, \mathrm{mmHg}$ & $72.95 \pm 1.52$ & $75.81=1.39$ & $88.39=1.05$ & $91.39 \pm 1.02$ & $80.90 \pm 8.39$ \\
\hline ABP Daytime PP, mmHg & $47.78 \pm 1.05$ & $48.49 \pm 0.85$ & $54.73 \pm 2.05$ & $61.96 \pm 4.54$ & $52.75 \pm 6.45$ \\
\hline ABP Night-time SBP, mmHg & $115.53 \pm 2.75$ & $117.44 \pm 1.77$ & $130.03 \pm 4.31^{-}$ & $134.12 \pm 5.18$ & $123.21=9.06$ \\
\hline ABP Night-time DBP, mmHg & $-69.96 \pm 2.38$ & $72.72 \pm 2.89$ & $83.28 \pm 2.11$ & $84,41=2,12$ & $76.50 \pm 7.07$ \\
\hline $\mathrm{ABP}$ Night-time $\mathrm{PP}, \mathrm{mmHg}$ & $45.57 \pm 3.73$ & $44.72 \pm 3.15$ & $46.76 \pm 4.56$ & $49.71 \pm 5.65$ & $46.72 \pm 4.73$ \\
\hline $\begin{array}{l}\text { Nocturnal SBP Dipping, } \\
\text { Nocturmal DBP Dipping, \% }\end{array}$ & $\begin{array}{l}4.29=2.47 \\
4.05 \pm 3.99\end{array}$ & $\frac{5.50=1.88}{3.99=5.09}$ & $\begin{array}{l}9.10=3.77 \\
5.76 \pm 2.78\end{array}$ & $\frac{12.46 \pm 4.13}{7.62 \pm 2.66}$ & $\begin{array}{l}7.42 \pm 4.64 \\
5.26 \pm 3.96\end{array}$ \\
\hline
\end{tabular}

Note.CH-Controlled hypertension, WCEUH-White-Coat effect in uncontrolled hypertension, MEUH-Masked effect in uncontrolled hypertension, SUH-Sustained uncontrolled hypertension, SBP-Systolic blood pressure, DBP-Diastolic blood pressure, PP-Pulse pressure, ABP-Ambulatory blood pressure. 
Comparing means between BP pattern groups, results specified in table 3, we observed mean clinic SBP and DBP normal in $\mathrm{CH}$ and MEUH, and raised in SUH and WCEUH groups, and mean twenty-four hour SBP and DBP normal in $\mathrm{CH}$ and WCEUH and raised in SUH and MEUH, in agreement with the definitions mentioned above. We can say though clinic BP means are closed as values for $\mathrm{CH}$ and MEUH groups(127.27 $\pm 6.22 \mathrm{mmHg}$ vs. $127.43 \pm 5.36$ $\mathrm{mmHg})$ and for WCEUH and SUH groups(161.86 \pm 10.73 $\mathrm{mmHg}$ vs. $163.95 \pm 13.36 \mathrm{mmHg}$ ). Twentyfour hour ambulatory blood pressure means are raised in WCEUH group versus $\mathrm{CH}$ group $(122.86 \pm 1.18 / 75.16 \pm 0.88 \mathrm{mmHg}$ vs. $119.64 \pm 1.53 / 72.33 \pm 1.26 \mathrm{mmHg}$ ) and in SUH group versus MEUH group $(149.31 \pm 4.46 / 89.93 \pm 0.87 \mathrm{mmHg}$ vs. $140.37 \pm 2.25 / 87.31 \pm 0.88 \mathrm{mmHg}$ ), these reports remain preserved also for daytime and night-time blood pressure within these groups.

Olesen et al[21]manage to show that 24hPP is a good predictor for LVH (1.24 (1.09-1.42) $p<0.01$ for target organ damage). The results in our study for 24hPP(table 3) show that: mean PP is greater in $\mathrm{SUH}$ and MEUH than in $\mathrm{CH}$ and WCEUH; daytime PP is more than $60 \mathrm{mmHg}$ only in SUH group, in MEUH, WCEUH and CH is still raised but it doesn't reach these value; night-time PP does not reach $60 \mathrm{mmHg}$, but it is still raised in all BP pattern groups. Considering what Olesen et al.[21] found out,and the results of our study we could foresee that PP is important for cardiac damage management, but we wanted instead to show thatnocturnal SBP and DBP dipping factor correlates with $\mathrm{LVH}$ as others managed to show in their studies[22,23]. We divided the cohort into two groupsone with LVH with a total of 135 patients and one without LVH with a total of 108 patients. Nocturnal dipping divided the samplebetween systolic blood pressure dippers and diastolic blood pressure dippers(fig. 2).

Results from table 4 and table 5 show an important association between BP category pattern, left ventricular hypertrophy and the number of patients with elevated nighttime BP (non-dippers in our case)especially in WCEUH followed by MEUH and SUH $(p<0.01)$ which regards nocturnal SBP dipping and more in SUH, MEUH followed by WCEUH which regards nocturnal DBP dipping $(p<0.05)$. Also in the $\mathrm{CH}$ group more than half of the patients were non-dippers with LVH, $p<0.01$ for nocturnal SBP dipping factor and less than half for nocturnal DBP dipping factor( $p<0.05)$. Meta-analysis[19], and many research articles[15, 23-25] established important proves that masked effect and sustained hypertension are risk factors for target organ damage such as LVH. In our study, we found an important number of patients with LVH even after a year of treatment and elevated nocturnal non-dipping factor which could mean their cardiovascular risk is even bigger.

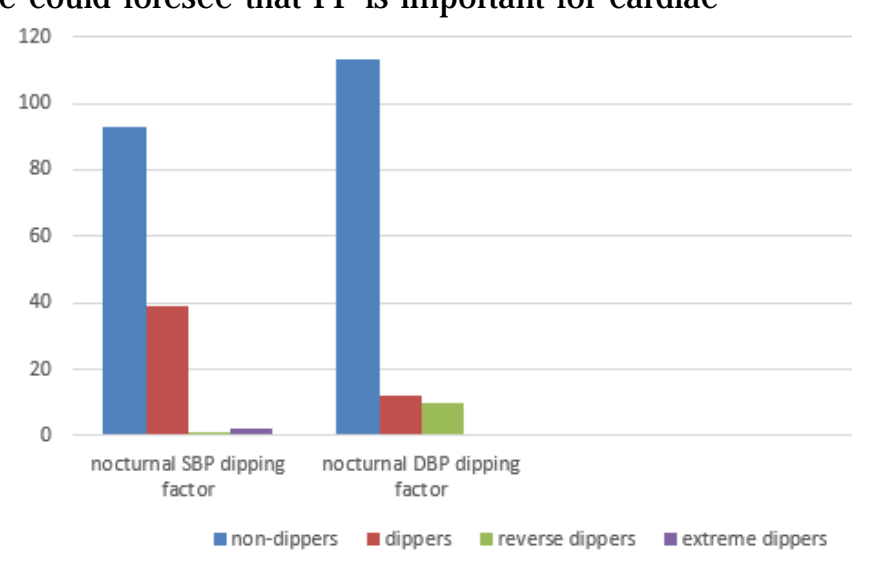

Fig. 2. Dipping category in the study cohort

Table 4

NOCTURNAL SBP DIPPING*BP PATTERN GROUPS*LEFT VENTRICULAR HYPERTROPHY

\begin{tabular}{|c|c|c|c|c|c|c|c|c|}
\hline \multirow{2}{*}{\multicolumn{3}{|c|}{ Left Ventricular Hypertrophy }} & \multicolumn{4}{|c|}{ Hypertension Patterns } & \multirow[b]{2}{*}{$\begin{array}{l}\text { Total } \\
\mathrm{n}=243 \\
\end{array}$} & \multirow{2}{*}{$\frac{p \text {-value }}{<0.01}$} \\
\hline & & & $\begin{array}{l}\begin{array}{l}\mathrm{CH} \\
\mathrm{n}=102\end{array} \\
53\end{array}$ & $\begin{array}{l}\text { WCEUH } \\
\mathbf{n}=34\end{array}$ & $\begin{array}{l}\begin{array}{l}\text { MEUH } \\
n=46\end{array} \\
13\end{array}$ & $\begin{array}{l}\begin{array}{l}\text { SUH } \\
n=61\end{array} \\
8\end{array}$ & & \\
\hline No- & $\begin{array}{l}\text { Noctumal SBP } \\
\text { Dipping }\end{array}$ & $\begin{array}{l}\text { non- } \\
\text { dippers }\end{array}$ & 44 & 15 & 10 & 9 & 78 & $<0.01^{-}$ \\
\hline Tótal & $\begin{array}{l}\text { Nocturnal SBP } \\
\text { Dipping }\end{array}$ & $\begin{array}{l}\text { non- } \\
\text { dippers }\end{array}$ & 97 & 34 & 23 & 17 & 171 & $<0.01^{-}$ \\
\hline
\end{tabular}

Note.CH-Controlled hypertension, WCEUH-White-Coat effect uncontrolled hypertension, MEUH-Masked effect uncontrolled hypertension, SUH-Sustained uncontrolled hypertension. SBP-Systolic Blood Pregsure, p value-level of gienificance $<0,05$

Table 5

NOCTURNAL DBP DIPPING*BP PATTERN*LEFT VENTRICULAR HYPERTROPHY

\begin{tabular}{|c|c|c|c|c|c|c|c|c|}
\hline \multirow{2}{*}{\multicolumn{3}{|c|}{ Left Ventricular Hypertrophy }} & \multicolumn{4}{|c|}{ Hypertension Patterns } & \multirow[b]{2}{*}{$\begin{array}{l}\text { Total } \\
n=243\end{array}$} & \multirow[b]{2}{*}{$\mathrm{p}$-value } \\
\hline & & & $\begin{array}{l}\mathrm{CH} \\
\mathrm{n}=102\end{array}$ & $\begin{array}{l}\text { WCEUH } \\
\mathbf{n}=34\end{array}$ & $\begin{array}{l}\text { MEUH } \\
n=46\end{array}$ & $\begin{array}{l}\text { SUH } \\
n=61\end{array}$ & & \\
\hline No & $\begin{array}{l}\text { Nocturnal DBP } \\
\text { Dipping }\end{array}$ & non-dippers & -35 & 11 & 18 & 20 & 84 & $<0.01$ \\
\hline
\end{tabular}

Note CH-Controlled hypertension, WCEUH-White-Coat effect untreated hypertension, MEUH-Masked Effect Uncontrolled Hypertension,

SUH-Sustained Uncontrolled Hypertension, DBP-Diastolic Blood Pressure, p value-level of significance $<0,05$ 


\section{Study limitation}

This cross-sectional study has potential limitations. First of all, we used electrocardiography for establishing the presence of LVH instead of echocardiography which is more accurate. Secondly can occur biases because we have small groups of reverse dippers, dippers and extreme dippers, and a large group of non-dippers.

\section{Conclusions}

In conclusion at the subjectswhich are known like hypertensives and have had LVH determined electrocardiographic, ABPM pattern like masked or uncontrolled $B P$ have a raising cardiovascular risk that could be reduced if the patients are well investigated by general practitioners in primary health care.

\section{References}

1.DOROBANTU M., DARABONT RO., BADILA E., GHIORGHE S., Int J Hypertens., 970694, Feb. 1, 2010.

2. DOROBANTU M., DARABONT R., GHIORGHE S., ARSENESCUGEORGESCU C., MACARIE C., MITU F., LIGHEZAN D., MUSETESCU R., POP C., ARDELEANU E., CRAIU E., TAUTU OF., J HYPERTENS., 32, no.1, 2014, p.39-47.

3.DOROBANTU M., TAUTU OF., DIMULESCU D., SINESCU C., GUSBETHTATOMIR P., ARSENESCU-GEORGESCU C., MITU F., LIGHEZAN D., POP C., BABES K., GIUCA A., BRANZA I., UDRESCU M., HERDEA V., DARABONT R., J HYPERTENS., 36, no.3, 2018, p. 690-700.

4. O'BRIEN E., ASMAR R., BEILIN L., IMAI Y., MALLION J M., MANCIA G., MENGDEN T., MYERS M., PADFIELD P., PALATINI P., PARATI G., PICKERING T., REDON J., STAESSEN J., STERGIOU G., VERDECCHIA P., J Hypertens., 21, 2003,p.821-848.

5.PARATI G., STERGIOU GS., ASMAR R., BILO G., DE LEEUW P., IMAI Y., KARIO K., LURBE E., MANOLISA., MENGDEN T., O'BRIEN E., OHKUBO T., PADFIELD P., PALATINI P., PICKERING T., REDON J., REVERA M., RUILOPE LM., SHENNAN A., STAESSEN JA., TISLER A., WAEBER B., ZANCHETTI A., MANCIA G., J Hypertens,26, 2008, p.1505-1526.

6. PIEPOLI MF., HOES AW., AGEWALL S., et al., Eur Heart J.,37, no.29, 2016, p. 2315-2381.

7. STERGIOU G., ARGYRAKI K., MOYSSAKIS I., MASTORANTONAKIS S., ACHIMASTOSA., KARAMANOS V., ROUSSIASL.,American J ournal of Hypertension,20, no. 6, 2007, p. 616-621.

8.MCDONALD C., PEARCE MS., WINCENCIAK J., KERR S.R.J., NEWTON $J$ L., American Journal of Hypertension, 29, no.5, 2016, p.560-567.

9. SHIMBO D., ABDALLA M., FALZON L., TOWNSEND RR., MUNTNER P., Ann Intern Med., 163, no. 9, 2015, p. 691-700.

10.MARCHIANDO RJ., ELSTON MP., Am Fam Physician, 67, no.11, 2003,p. $2343-50$.

11.CUSPIDI C., LONATI L., SAMPIERI L., MICHEV I., MACCA G., ROCANOVA J.., SALERNO M., FUSI V., LEONETTI G., ZANCHETTI A., J Hypertens., 18, no. 6, 2000, p. 803-9.
12. BLIZIOTIS IA., DESTOUNIS A., STERGIOU GS., J Hypertens., 30, 2012, p.1289-1299.

13. FARHAN H., AL-HASANI M., MISBAH M., SALLAM M., SULTAN QABOOS UNIV MED J.,10, NO. 3, 2010, P. 370-6.

14.O'BRIEN E., PARATI G., STERGIOU G., ASMAR R., BEILIN L., BILO G., CLEMENT D., DE LA SIERRA A., DE LEEUW P., DOLAN E., FAGARD R., GRAVES J., HEAD GA., IMAI Y., KARIO K., LURB E., MALLION J-M., MANCIA G., MENGDEN T., MYERS M., OGEDEGBE G., OHKUBO T., OMBONI S., PALATINI P., REDON J., RUILOPE LM., SHENNAN A., STAESSEN JA., VAN MONTFRANS G., VERDECCHIA P., WAEBER B., WANG J., ZANCHETTI A., ZHANG Y., J Hypertens., 31, 2013, p.17311768.

15.PIERDOMENICO SD., PIERDOMENICO AM., COCCINA F., PORRECA E., American Journal of Hypertension, 30, no. 11, 2017, p. 1106-1111. 16.LIMA NK., MORIGUTI JC., FERRIOLLI E., J Geriatr Cardiol., 13, no. 8, 2016, p. 672-678.

17.CUSPIDI C., SALA C., TADIC M., et al., J Clin Hypertens., 19, 2017, p. 713-721.

18.DOROBANPU M., DARABONT R., GHIORGHE S., BABES K., POP D., TOMA D., VASILESCU M., DOBREANU M., TAUTU O., ROM. J. INTERN. MED.,50, no. 4, 2012, p. 285-296.

19.PIERDOMENICO SD., CUCCURULLO F.,Am J Hypertens., 24, 2011,p. 52-58.

20.FAGARD RH., VAN DEN BROEKE C., DE CORT P., J ournal of Human Hypertension, 19,2005, p. 801-807.

21.OLESEN TB., STIDSEN JV., BLICHER MK., PAREEK M, RASMUSSEN S., VISHRAM-NIELSEN J.KK., OLSEN MH., Hypertension, 70, 2017,p.10341041.

22.HERMIDA RC., CRESPO JJ., OTERO A., DOMINGUEZ-SARDINA M., MOYAA., RIOS MT., CASTINEIRA MC., CALLEJASPA., POUSA L., SINEIRO E., SALGADO JL., DURAN C., SANCHEZ JJ., FERNANDEZ JR., MOJ ON A., AYALA DE., HYGIA PROJ ECT INVESTIGATORS.,EUR HEART J., 39,NO.47,2018,P.P159-4171.

23. DRAWZ PE., ALPER AB., ANDERSON AH., BRECKLIN CS., CHARLESTON J., CHEN J., DEO R., FISCHER MJ ., HE J., HSU CY., HUAN Y., KEANE MG., KUSEK JW., MAKOS GK., MILLER ER 3RD., SOLIMAN EZ., STEIGERWALT SP., TALIERCIO JJ., TOWNSEND RR., WEIR MR., WRIGHTJT J R., XIE D., RAHMAN M.CHRONIC RENAL INSUFFICIENCY COHORT STUDY INVESTIGATORS.,Clin J Am SOC Nephrol., 11,no.4, 2016 p.642-52.

24.GHOSH AK., HARDY RJ ., FRANCISDP., CHATURVEDI N., PELLERIN D., DEANFIELD J., KUH D., Mayet I ., HUGHES AD., MEDICAL RESEARCH COUNCIL NATIONAL SURVEY OF HEALTH AND DEVELOPMENT (NHSD) SCIENTIFIC AND DATA COLLECTION TEAM., Eur Heart J., 35, no.46, 2014, p.3287-95.

25.EDISON ES., YANO Y., HOSHIDE S., KARIO K., Am J Hypertens., 28, no. 4,2015,p.527-34.

Manuscript received: 28.09 .2018 